\title{
Meta Analysis the Effect of Intervention Based School toward Nutrition on Body Mass Index
}

\author{
Wulandari'), Yulia Lanti Retno Dewi²), Bhisma Murti') \\ 1)Masters Program in Public Health, Universitas Sebelas Maret \\ 2)Department of Public Health, Faculty of Medicine, Universitas Sebelas Maret
}

\section{ABSTRACT}

Background: Body mass index (BMI) is a metric used to define anthropometric characteristics and classify interpretations of individual fatness indexes. The International Association For The Study Of Obesity (IASO) and the International Obesity Task Force (IOTF) calculate that 200 million school children worldwide are overweight or obese. This study aims to estimate the magnitude of the effect of school-based interventions for nutrition on body mass index based on a number of previous primary studies. Subjects and Method: This study is a systematic study and meta-analysis, with the following PICO Population = students $($ SMP) and $($ SMA) with obesity. Intervention= School-based interventions for nutrition. Comparison= no intervention. Outcomes in the form of body mass index. The articles used in this study were obtained from several databases, including PubMed, ScienceDirect and Google Scholar. This article was collected for 1 month. The keywords to search for articles were as follows: "Schoolbased intervention" AND "Nutrition " "AND " Obesity " AND "BMI” OR "Body Mass Index"
AND "Randomized Controlled Trial". The articles included in this study are full text articles with a Randomized Controlled Trial study design. Articles were collected using PRISMA flow diagrams. Articles were analyzed using the Review Manager 5.3 aplikasi application

Results: A total of 9 articles were reviewed in this meta-analysis. The study showed that schoolbased interventions for nutrition had an effect on lowering body mass index (Standarized Mean Difference $=-0.23 ; 95 \% \mathrm{CI}=-0.39$ to $0.007 \mathrm{p}=$ 0.005).

Conclusion: School-based interventions for nutrition lower body mass index.

Keywords: school-based interventions, nutrition, obesity, Body mass index.

\section{Correspondence:}

Wulandari. Masters Program In Public Health, Universitas Sebelas Maret. Jl. Ir. Sutami 36A, Surakarta 57126, Central Java, Indonesia. Email : Wulano74@gmail.com.

\section{Cite this as:}

Wulandari, Dewi YLR, Murti B (2021). Meta Analysis the Effect of Intervention Based School toward Nutrition on Body Mass Index. J Epidemiol Public Health. 06(02): 192-200. https://doi.org/10.26911/jepublichealth.2021.06.02.06.

(ㄷ) Journal of Maternal and Child Health is licensed under a Creative Commons Attribution-NonCommercial-ShareAlike 4.o International License.

\section{BACKGROUND}

Body mass index (BMI) is a metric that is currently used to define anthropometric characteristics in children, adolescents, adults and to classify into interpretation groups that represent the individual fatness index (Nuttal, 2015). Body mass index is widely used as a risk factor for the development or prevalence of several health problems. Obesity is excess body fat mass (Schwartz, 2017).

Most adolescents with obesity impact into adulthood. About $55 \%$ of obese children continue to be obese in adolescence and $80 \%$ will continue to be obese in adulthood and about $70 \%$ will remain obese over the age of 30 years (Simmonds, 2016), so efforts are needed to reduce the nutritional status of obesity. in children to normal nutrition. 
Children and adolescents with obesity put them at risk for both short and long term psychological and non-communicable diseases (NCD). In the short term psychologically, children are at risk for depression, anxiety, low self-esteem, a range of emotional and behavioral disorders, asthma, low-grade systemic inflammation, liver complications, and musculoskeletal problems (Cesare, 2019). The number of children who are predicted to be obese in 2025 is 206 million and in 2030 is 254 million (WOF, 2019).

Obesity in adolescence has reached epidemic proportions worldwide, with the prevalence of obesity increasing at least 4fold over the past 35 years. Approximately 13.7 million children and adolescents are obese. The prevalence of obesity is at the age of 12 to 19 years (CDC, 2020). The International Association For The Study Of Obesity (IASO) and the International Obesity Task Force (IOTF) calculate that 200 million school children worldwide are overweight or obese (WHO, 2018).

Developed countries tend to have higher rates of obesity than developing countries (Ogden, 2020). Nutritional interventions can alter obesity risk and metabolic conditions, reduce morbidity and mortality in the population by improving diet quality, modifying cardiometabolic risk, and promoting weight loss (Wing, 2011). Prevention of obesity in adolescence is a public health priority (Alberga, 2012). Interventions focus on reducing calorie intake and intake of sugary drinks, improving the quality of snacks, increasing fruit and vegetable intake, and promoting moderate exercise (NHLBI, 2015). School-based interventions for nutrition can lead to a decrease in body mass index (Johns, 2014). A decrease in BMI of 5\% or more is associated with a lower risk of cardiovascular disease (Wing, 2011).

School-based nutrition policies and programs may be an effective mechanism to contribute to attainable health standards. Schools play an important role in promoting nutrition by providing access to children from various socioeconomic backgrounds (Khambalia, 2011). A global nutrition policy review conducted in 2016-2017 reported that $89 \%$ of 160 countries reported implementing school health and nutrition programs. Middle school interventions that incorporate materials on improving healthy eating patterns report a reduction in obesity (Cadzow, 2015).

NCD prevention strategies, such as school-based interventions, are critical because they are feasible and relatively inexpensive approaches that reach large populations. School-based interventions involving individual and environmental components have shown a small to moderate effect for the prevention of overweight in adolescents (Khambalia, 2012). This whole process resulted in a multicomponent (individual/ environmental) intervention program aimed at reducing sugar intake, increasing daily fruit and vegetables, reducing unhealthy snack intake, increasing healthy breakfast intake (Royen, 2015).

This study aimed to examine the influence of school-based interventions for nutrition on BMI in students with obesity using systematic review and meta-analysis.

\section{SUBJECTS AND METHOD}

\section{Study Design}

This is a systematic study and meta-analysis. The articles used in this study were obtained from several databases including PubMed, ScienceDirect and Google Scholar. The keywords to search for articles were as follows: "School-based intervention" AND "Nutrition" " AND "Physical Activity" "AND " Obesity "AND "BMI” OR "Body Mass Index"

\section{Inclusion Criteria}

The articles included in this study are full paper articles with a randomized controlled trial study design. The research subjects were 
junior high school and high school students. Selected articles provide interventions in the form of school-based interventions for nutrition with body mass index outcomes.

\section{Exclusion Criteria}

The articles published in this study were articles published before 2010 and articles that did not include the mean SD value.

\section{Operational Definition}

The search for articles was carried out by considering the eligibility criteria defined using the PICO model. The population in this study were middle school and high school students with obesity, the intervention was in the form of school-based intervention for nutrition, comparison, which was no intervention, and the outcome in the form of a body mass index.

School-based intervention for nutrition is a strategic program to manage and provide students with consistent and accurate health information that is clear and consistent about nutrition and healthy eating patterns. Instrument: School-based program with categorical measurement scale.

Body mass index is a measure of body weight adjusted for height, calculated as weight in kilograms divided by height squared in meters $\left(\mathrm{kg} / \mathrm{m}^{2}\right)$. Instruments: Scales and stadiometers with continuous measuring scale.

\section{Data Analysis}

Data processing is carried out by Review Manager (RevMan 5.3) by calculating the mean difference to determine the combined research model and form the final result of the meta-analysis.

\section{RESULTS}

The process of searching for articles by searching through a database with journals can be seen in Figure 1 .

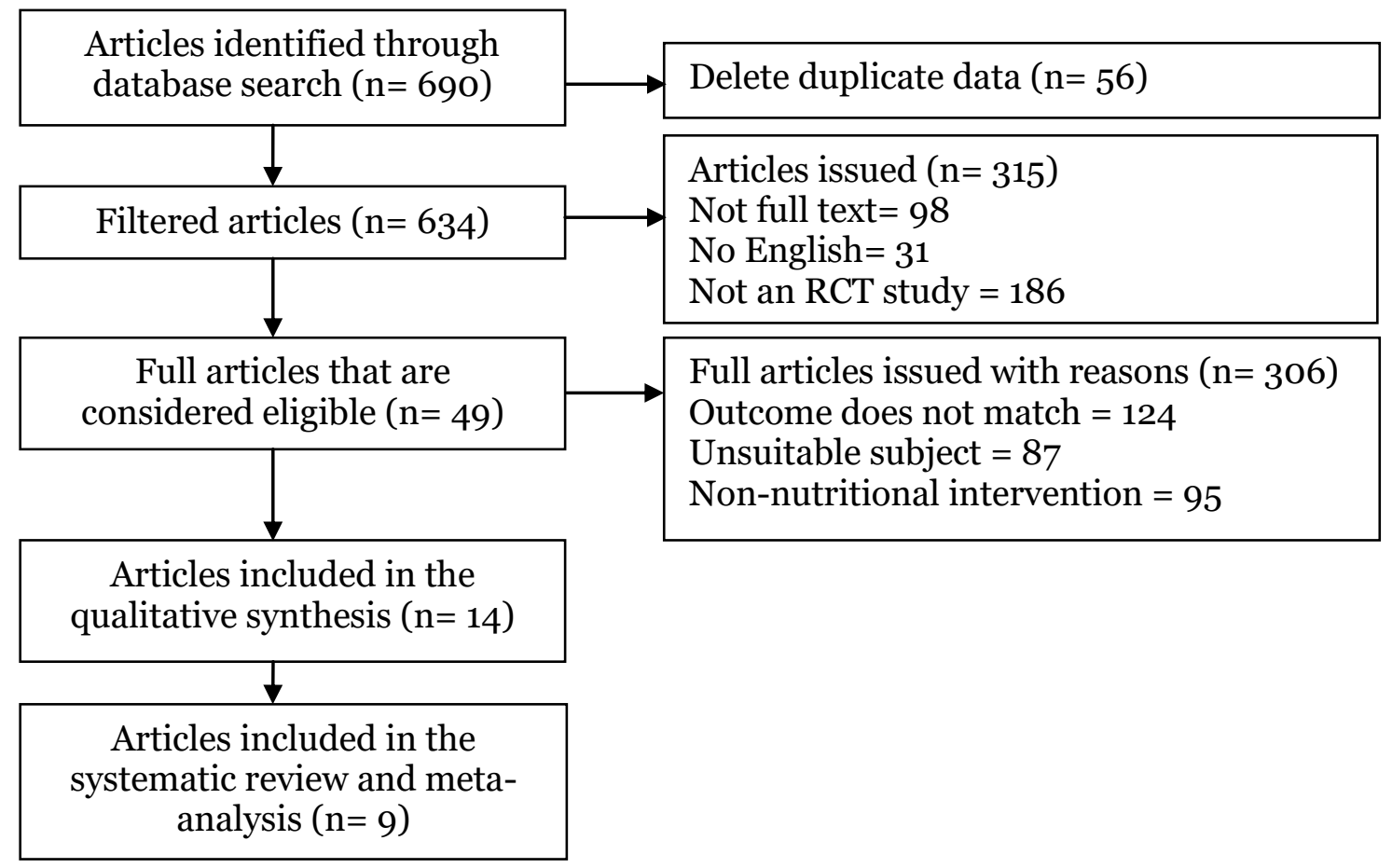

\section{Figure 1. PRISMA flow diagram}

There were 690 articles identified from the database, after the process of deleting duplicate articles, 634 articles were obtained with 319 of them meeting the requirements. Articles were excluded for several reasons, so 
Wulandari et al./ Effect of Intervention Based School toward Nutrition on Body Mass Index

that 9 articles were included in the synthesis and meta-analysis studies.

There were 9 articles from 4 continents, namely America, Europe, Asia and Africa. 4 studies from the Americas, 1 study from the European continent, 3 studies from the Asian continent, and 1 study from the African continent.

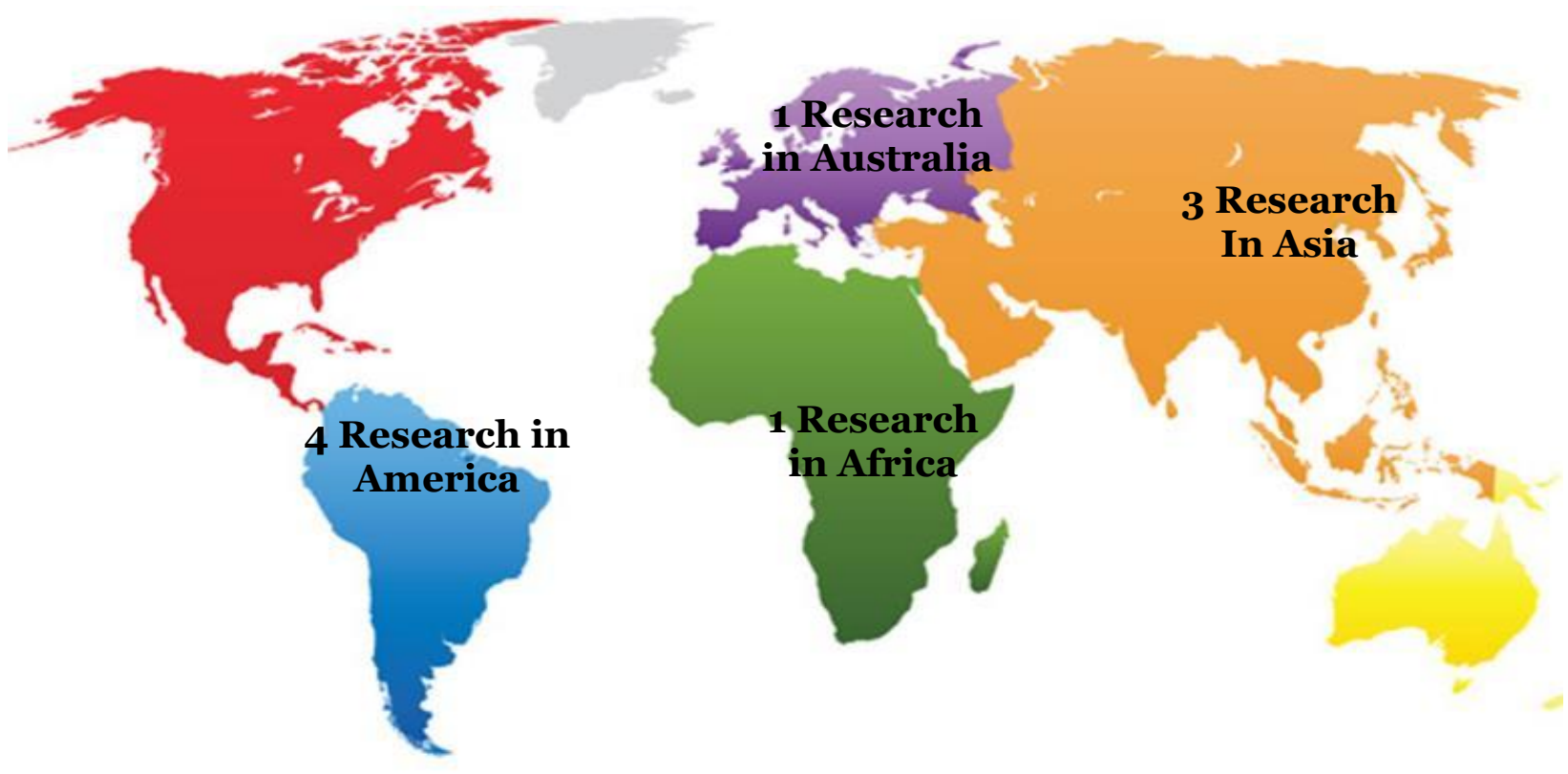

Figure 2. Map of distribution of areas of influence of school-based interventions for nutrition on body mass index

\section{School-based interventions for nutrition on body mass index}

9 articles prove that there is a relationship between school-based interventions for nutrition and body mass index.

Based on the results of the forest plot (Figure 3), it showed that the school-based intervention for nutrition reduced the body mass index -0.23 times and was statistically significant $(\mathrm{p}=0.005)$. The heterogeneity of the research data shows $\mathrm{I}^{2}=81 \%$ so that the distribution of the data is said to be heterogeneous (random effect model).

\section{a. Forest plot}

\begin{tabular}{|c|c|c|c|c|c|c|c|c|c|c|c|c|}
\hline \multirow[b]{2}{*}{ Study or Subgroup } & \multicolumn{3}{|c|}{ Nutrition } & \multicolumn{3}{|c|}{ No intervention } & \multicolumn{2}{|c|}{ Std. Mean Difference } & \multirow{2}{*}{\multicolumn{3}{|c|}{$\begin{array}{r}\text { Std. Mean Difference } \\
\text { IV, Random, } 95 \% \mathrm{CI}\end{array}$}} & \\
\hline & Mean & SD & Total & Mean & SD & Total & Weight & IV, Random, 95\% Cl & & & & \\
\hline Andrade 2016 & 1.34 & 2.4 & 550 & 2.85 & 3.71 & 553 & $16.3 \%$ & $-0.48[-0.60,-0.36]$ & & $=$ & & \\
\hline Bonsergent 2013 & -0.2 & 1.1 & 37 & 1.6 & 1.2 & 17 & $4.5 \%$ & $-1.57[-2.22,-0.92]$ & & & & \\
\hline Craig 2010 & -0.1 & 1.99 & 107 & 0.2 & 2.2 & 101 & $11.7 \%$ & $-0.14[-0.41,0.13]$ & & & & \\
\hline Florence 2020 & -0.328 & 0.734 & 111 & $=0.36$ & 0.838 & 111 & $12.0 \%$ & $0.04[-0.22,0.30]$ & & & & \\
\hline Haiquan 2017 & 0.5 & 2.6 & 4934 & 1 & 2 & 4933 & $17.7 \%$ & $-0.22[-0.26,-0.18]$ & & - & & \\
\hline In-Iw 2012 & 0.53 & 1.16 & 25 & 0.51 & 1.57 & 24 & $5.5 \%$ & $0.01[-0.55,0.57]$ & & & & \\
\hline Mihas 2010 & -0.1 & 1.99 & 107 & 0.2 & 2.2 & 101 & $11.7 \%$ & $-0.14[-0.41,0.13]$ & & & & \\
\hline Pbert 2016 & -0.15 & 0.78 & 54 & -0.04 & 0.69 & 57 & $9.0 \%$ & $-0.15[-0.52,0.22]$ & & & & \\
\hline Singhal 2010 & -0.07 & 0.71 & 99 & -0.06 & 1.11 & 102 & $11.6 \%$ & $=0.01[-0.29,0.27]$ & & & & \\
\hline Total $(95 \% \mathrm{Cl})$ & & & 6024 & & & 5999 & $100.0 \%$ & $-0.23[-0.39,-0.07]$ & & & & \\
\hline \multicolumn{13}{|c|}{ 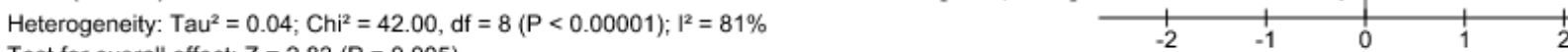 } \\
\hline
\end{tabular}

Figure 3. Forest plot of the effect of school-based interventions for nutrition on Body mass index 
Table 1. Assessment of Study quality

\begin{tabular}{|c|c|c|c|c|c|c|c|c|c|}
\hline \multirow[b]{2}{*}{ Questions of checklist } & \multicolumn{9}{|c|}{ Publication (Author and Year) } \\
\hline & $\begin{array}{l}\text { Singhal } \\
\text { et al. } \\
\text { (2010) }\end{array}$ & $\begin{array}{l}\text { Andrande } \\
\text { et al. } \\
\text { (2016) }\end{array}$ & $\begin{array}{l}\text { Craig et } \\
\text { al. (2010) }\end{array}$ & $\begin{array}{l}\text { Mihas } \\
\text { et al. } \\
\text { (2010) }\end{array}$ & $\begin{array}{l}\text { Bonsergent } \\
\text { et al. (2013) }\end{array}$ & $\begin{array}{l}\text { Pbert } \\
\text { et al. } \\
\text { (2016) }\end{array}$ & $\begin{array}{l}\text { In-lw et } \\
\text { al. (2012) }\end{array}$ & $\begin{array}{l}\text { Haiquan } \\
\text { et al. } \\
(\mathbf{2 0 1 7})\end{array}$ & $\begin{array}{l}\text { Florence } \\
\text { et al. } \\
(\mathbf{2 0 2 0})\end{array}$ \\
\hline Does this study address a clear research focus? & 1 & 1 & 1 & 1 & 1 & 1 & 1 & 1 & 1 \\
\hline $\begin{array}{l}\text { Is the Randomized Controlled Trial research method } \\
\text { appropriate to answer the research question? }\end{array}$ & 1 & 1 & 1 & 1 & 1 & 1 & 1 & 1 & 1 \\
\hline $\begin{array}{l}\text { Are there enough subjects in the study to establish that the } \\
\text { findings did not occur by chance? }\end{array}$ & 1 & 1 & 1 & 1 & 1 & 1 & 1 & 1 & 1 \\
\hline $\begin{array}{l}\text { Were subjects randomly allocated to the experimental and } \\
\text { control groups? If not, could this be biased? }\end{array}$ & 1 & 1 & 1 & 1 & 1 & 1 & 1 & 1 & 1 \\
\hline Are inclusion/exclusion criteria used? & 1 & 1 & 1 & 1 & 1 & 1 & 1 & 1 & 1 \\
\hline Were the two groups comparable at the start of the study? & o & 1 & 1 & O & 1 & o & 1 & 1 & 1 \\
\hline Were objective and unbiased outcome criteria used? & 1 & 1 & 1 & 1 & 1 & 1 & 1 & 1 & 1 \\
\hline $\begin{array}{l}\text { Are objective and validated measurement methods used in } \\
\text { measuring the results? If not, were results judged by } \\
\text { someone who did not know the group assignment (ie was } \\
\text { the assessment blinded)? }\end{array}$ & 1 & 1 & 1 & 1 & 1 & 1 & 1 & 1 & 1 \\
\hline Is effect size practically relevant? & 1 & O & 1 & $\mathrm{O}$ & 1 & 1 & $\mathrm{O}$ & 1 & 1 \\
\hline $\begin{array}{l}\text { How precise is the estimate of the effect? Is there a } \\
\text { confidence interval? }\end{array}$ & 1 & 1 & $\mathrm{O}$ & 1 & 1 & 1 & 1 & 1 & o \\
\hline $\begin{array}{l}\text { Could there be confounding factors that have not been } \\
\text { taken into account? }\end{array}$ & O & O & O & O & O & O & O & O & o \\
\hline Are the results applicable to your research? & 1 & 1 & 1 & 1 & 1 & 1 & 1 & 1 & 1 \\
\hline Total & 10 & 10 & 9 & $\mathbf{1 1}$ & 10 & 10 & 10 & 11 & 10 \\
\hline
\end{tabular}

* In question item number 11, a score of o is given because the question is scored positive 
Wulandari et al./ Effect of Intervention Based School toward Nutrition on Body Mass Index

Table 2. Description of primary studies included in the primary study meta-analysis

\begin{tabular}{|c|c|c|c|c|c|c|c|}
\hline $\begin{array}{l}\text { Author } \\
\text { (Year) }\end{array}$ & Country & $\begin{array}{l}\text { Study } \\
\text { Design }\end{array}$ & Sample & $\begin{array}{c}\text { P } \\
\text { (Popula- } \\
\text { tion) }\end{array}$ & $\begin{array}{c}\text { I } \\
\text { (Intervention) }\end{array}$ & $\begin{array}{c}\mathrm{C} \\
\text { (Compa- } \\
\text { rison) }\end{array}$ & $\begin{array}{c}\text { O } \\
\text { (Outcome) }\end{array}$ \\
\hline $\begin{array}{l}\text { Singhal et } \\
\text { al. (2010) }\end{array}$ & India & $\begin{array}{l}\text { Randomized } \\
\text { Controlled } \\
\text { Trial. }\end{array}$ & $\begin{array}{l}\text { Nutritional intervention } \\
: 99 \text { No intervention } \\
: 102\end{array}$ & SHS & $\begin{array}{l}\text { Look at the effectiveness of interventions for } \\
\text { nutrition in adolescents and change knowledge } \\
\text { related to nutrition, diet and lifestyle practices. }\end{array}$ & $\begin{array}{l}\text { No inter- } \\
\text { vention }\end{array}$ & $\begin{array}{l}\text { Body mass } \\
\text { index }\end{array}$ \\
\hline $\begin{array}{l}\text { Craig et al. } \\
(2010) .\end{array}$ & Mexico & $\begin{array}{l}\text { Randomized } \\
\text { Controlled } \\
\text { Trial. }\end{array}$ & $\begin{array}{l}\text { Nutritional intervention: } \\
37 \text { No intervention: } 101\end{array}$ & JHS & $\begin{array}{l}\text { Seeing the effectiveness of interventions for } \\
\text { nutrition in adolescents, providing an environ- } \\
\text { ment to support healthy eating habits, education } \\
\text { about healthy snacks }\end{array}$ & $\begin{array}{l}\text { No inter- } \\
\text { vention }\end{array}$ & $\begin{array}{l}\text { Body mass } \\
\text { index }\end{array}$ \\
\hline $\begin{array}{l}\text { Mihas et al. } \\
(2010)\end{array}$ & $\begin{array}{l}\text { United } \\
\text { States of } \\
\text { America }\end{array}$ & $\begin{array}{l}\text { Randomized } \\
\text { Controlled } \\
\text { Trial. }\end{array}$ & $\begin{array}{l}\text { Nutrition intervention : } \\
107 \text { No intervention :17 }\end{array}$ & SHS & $\begin{array}{l}\text { This study compares the effects of health educa- } \\
\text { tion and nutrition education interventions in } \\
\text { schools (diet and nutrition intake) }\end{array}$ & $\begin{array}{l}\text { No inter- } \\
\text { vention }\end{array}$ & $\begin{array}{l}\text { Body mass } \\
\text { index }\end{array}$ \\
\hline $\begin{array}{l}\text { Pbert et al. } \\
(2016) \text {. }\end{array}$ & $\begin{array}{l}\text { United } \\
\text { States of } \\
\text { America }\end{array}$ & $\begin{array}{l}\text { Randomized } \\
\text { Controlled } \\
\text { Trial. }\end{array}$ & $\begin{array}{l}\text { Nutrition intervention : } \\
57 \text { No intervention :54 }\end{array}$ & SHS & $\begin{array}{l}\text { This study looks at the effect of program inter- } \\
\text { ventions on improving diet }\end{array}$ & $\begin{array}{l}\text { No inter- } \\
\text { vention }\end{array}$ & $\begin{array}{l}\text { Body mass } \\
\text { index }\end{array}$ \\
\hline $\begin{array}{l}\text { Bonsegent } \\
\text { et al. (2013) }\end{array}$ & French & $\begin{array}{l}\text { Randomized } \\
\text { Controlled } \\
\text { Trial. }\end{array}$ & $\begin{array}{l}\text { Nutrition intervention : } \\
2641 \\
\text { No intervention : } 2713\end{array}$ & SHS & $\begin{array}{l}\text { This study looks at the effects of the interven- } \\
\text { tion, development of nutritional knowledge and } \\
\text { skills, increasing the availability of healthy food }\end{array}$ & $\begin{array}{l}\text { No inter- } \\
\text { vention }\end{array}$ & $\begin{array}{l}\text { Body mass } \\
\text { index }\end{array}$ \\
\hline $\begin{array}{l}\text { In-lw et al. } \\
(2012)\end{array}$ & Thailand & $\begin{array}{l}\text { Randomized } \\
\text { Controlled } \\
\text { Trial. }\end{array}$ & $\begin{array}{l}\text { Nutritional intervention } \\
: 25 \text { No intervention : } 24\end{array}$ & JHS & $\begin{array}{l}\text { This study looked at the effects of an interactive } \\
\text { nutrition intervention, eating a healthy diet. }\end{array}$ & $\begin{array}{l}\text { No inter- } \\
\text { vention }\end{array}$ & $\begin{array}{l}\text { Body mass } \\
\text { index }\end{array}$ \\
\hline $\begin{array}{l}\text { Haiquan et } \\
\text { al. (2017) }\end{array}$ & $\begin{array}{l}\text { China } \\
\text { (Asia) }\end{array}$ & $\begin{array}{l}\text { Randomized } \\
\text { Controlled } \\
\text { Trial. }\end{array}$ & $\begin{array}{l}\text { Nutrition intervention : } \\
4934 \text { No intervention : } \\
4933\end{array}$ & JHS & $\begin{array}{l}\text { This study looks at the effects of school-based } \\
\text { interventions for comprehensive nutrition, } \\
\text { healthy eating habits }\end{array}$ & $\begin{array}{l}\text { No inter- } \\
\text { vention }\end{array}$ & $\begin{array}{l}\text { Body mass } \\
\text { index }\end{array}$ \\
\hline $\begin{array}{l}\text { Andrade et } \\
\text { al. (2016). }\end{array}$ & $\begin{array}{l}\text { United } \\
\text { States of } \\
\text { America }\end{array}$ & $\begin{array}{l}\text { Randomized } \\
\text { Controlled } \\
\text { Trial. }\end{array}$ & $\begin{array}{l}\text { Nutrition intervention : } \\
539 \text { No intervention : } \\
521\end{array}$ & JHS & $\begin{array}{l}\text { This study looks at the effect of the intervention. } \\
\text { A comprehensive school-based intervention } \\
\text { aimed at improving diet. }\end{array}$ & $\begin{array}{l}\text { No inter- } \\
\text { vention }\end{array}$ & $\begin{array}{l}\text { Body mass } \\
\text { index }\end{array}$ \\
\hline $\begin{array}{l}\text { Florence. } \\
(2020) \text {. }\end{array}$ & Kenya & $\begin{array}{l}\text { Randomized } \\
\text { Controlled } \\
\text { Trial. }\end{array}$ & $\begin{array}{l}\text { Nutrition intervention : } \\
\mathbf{1 1 1} \text { No intervention : } \mathbf{1 1 1}\end{array}$ & SHS & $\begin{array}{l}\text { Improve knowledge, attitudes and skills to } \\
\text { improve healthy eating behavior perilaku }\end{array}$ & $\begin{array}{l}\text { No inter- } \\
\text { vention }\end{array}$ & $\begin{array}{l}\text { Body mass } \\
\text { index }\end{array}$ \\
\hline
\end{tabular}

* Variables included in the meta-analysis 


\section{b. Funnel plot}

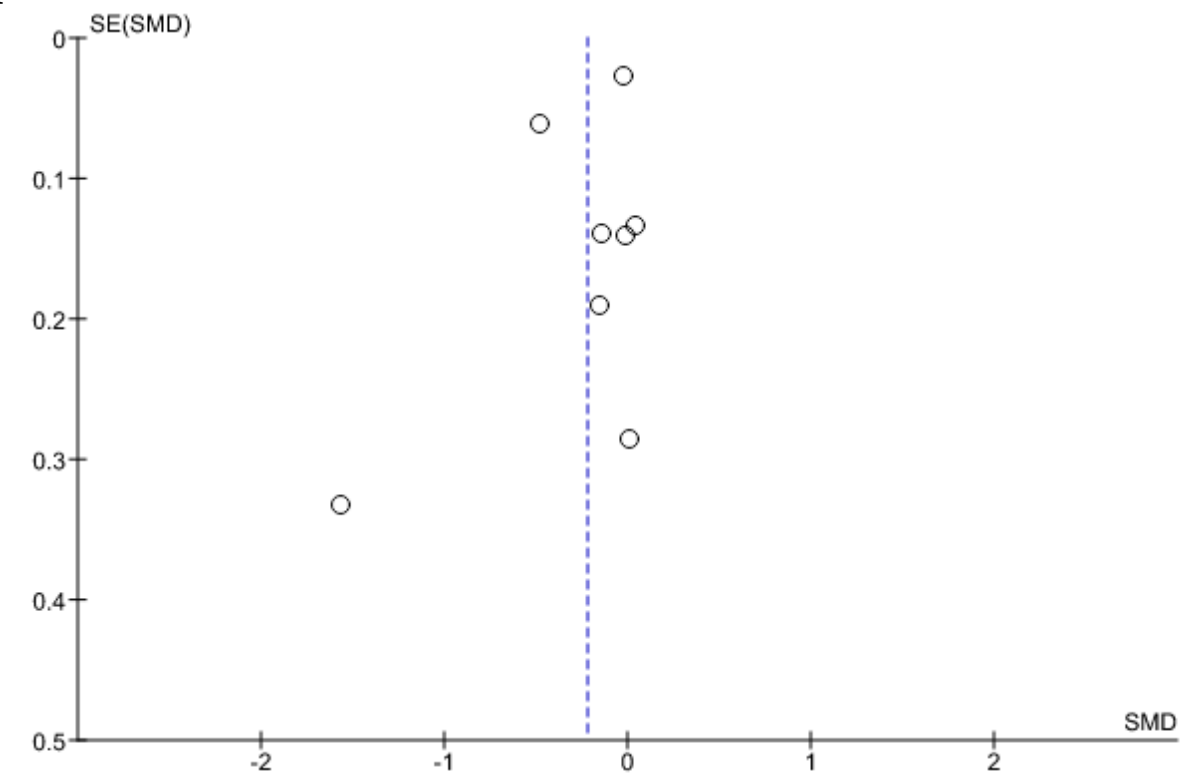

\section{Figure 4. Funnel plot of the effect of school-based interventions for nutrition on body mass index}

The funnel plot (figure 4) shows no bias where 2 plots are on the left and 6 plots are on the right, but there is 1 plot that does not appear because there are 2 articles with the same SMD value so it is likely that the plots will overlap. The plot on the left has a standard error between 0 and 0.4 and the plot on the right has a standard error between 0 and 0.3 .

\section{DISCUSSION}

This systematic review and meta-analysis research raised the theme of the effect of school-based interventions for nutrition and physical activity on body mass index (BMI). The independent variable is a school-based intervention for nutrition and the dependent variable analyzed is the body mass index of obese school students. The intervention was designed to reduce body mass index in obese middle and high school students with a randomized controlled trial design. Research that discusses school-based interventions for nutrition in adolescents with obesity is considered important because this problem is a problem in almost all countries, both developed and developing countries.

This systematic study and metaanalysis uses research that has controlled for confounding factors which can be seen from the terms of research inclusion, namely the Standardized mean difference. Estimates of the combined effect of school-based interventions for nutrition and physical activity were processed using RevMan 5.3 with the Continuous method. This method was used to analyze the effect size or standardized mean difference in bivariate data of two groups that had been controlled for confounding factors by randomization. The results of the systematic study and metaanalysis are presented in the form of forest plots and funnel plots.

The forest plot results showed that the school-based intervention for nutrition had an effect on reducing BMI by -0.23 times compared to the group that was not given the school-based intervention for nutrition. $(\mathrm{SMD}=-0.23 ; 95 \% \mathrm{CI}=-0.39$ to $0.07 \mathrm{p}=$ 0.005). The heterogeneity of the research data shows I $2=81 \%$ so that the distribution 
of the data is said to be heterogeneous (random effect model). This meta-analysis study provides strong evidence to support school-based interventions for nutrition as an effective intervention in reducing the body mass index of middle and high school students with obesity.

Several previous studies such as Wing et al., (2011), Vangal \& Puja Dudeja (2020), Johns et al (2014), Woodcock et al., (2011), Schwingshackl et al., (2014) reported schoolbased interventions for Nutrition can alter obesity risk and metabolic conditions, reduce morbidity and mortality in populations by improving diet quality, modifying cardiometabolic risk, and promoting a decrease in body mass index. Body mass index (BMI) is used to diagnose overweight and obesity (Casanova, 2013).

This study is in line with Singhal (2010) who reported that school-based interventions for nutrition were effective in reducing BMI in students with obesity. The results of the study emphasize that school-based interventions for nutrition provide increased knowledge related to nutrition, healthy eating habits. A global nutrition policy review conducted in 2016-2017 reported that $89 \%$ of 160 countries reported implementing school health and nutrition programs. The most frequently reported school health component was nutrition and nutrition education programs that were included in the school curriculum (61\%), followed by training of school staff on health and nutrition (56\%).

Craig (2010) reported that school-based interventions for nutrition were effective in lowering BMI in obese students. The results of the study emphasize that school-based interventions modify and encourage healthy eating and modify increased physical activity performance. This study is also supported by (Florence, 2020) which states that schoolbased interventions for nutrition are effective in reducing $\mathrm{BMI}$ in obese student.

\section{AUTHOR CONTRIBUTION}

Wulandari is the main researcher who selects topics, searches and collects research data. Yulia Lanti Retno Dewi and Bhisma Murti played a role in analyzing data and reviewing research documents.

\section{FUNDING AND SPONSORSHIP}

This study is self-funded.

CONFLICT OF INTEREST

There is no conflict of interest in this study.

\section{ACKNOWLEDGEMENT}

We are very grateful to the database providers, PubMed, Science Direct and Google Scholar.

\section{REFERENCES}

Andrade, Susana, Lachat, Carl, Cardon, Greet, Verstraeten, et al. (2016). Two years of school-based intervention program could improve the physical fitness among Ecuadorian adolescents at health risk: subgroups analysis from a cluster-randomized trial. BMC. 16(1): 51. doi:10.1186/s12887-016-0588-8

Bonsegent E, Agrinier N, Thilly N, Tessier S, Legrand K, Lecomte E, Aptel E, et al (2013). Overweight and obesity prevantion for adolescent. Am J Prev Med. 44(1): 1-10. https://doi.org/10.1016/j.amepre.2012.09.055.

Craig A, Jhonston, Chermaie T, Brian K, Farlin MC, Walker SC, Poston (2010). Effects of a school-based weight maintenance program for Mexican-American Children: Results at 2 years. J Obes. 18(3): 1-6. doi:10.1038/oby.2009.241.

Cardel MI, Atkinson MA, Taveras EM, Holm JC, Kelly AS (2020). Obesity treatment among adolescents. JAMA Pediatr. 174(6): 609-617. https://doi.org/10.1001/jamapediatrics.2020.0085. 
Wulandari et al./ Effect of Intervention Based School toward Nutrition on Body Mass Index

Cochrane (2014). RevMan 5.3 User Guide. Haiquan XU, Yanping, Qian, Xiaoqi, Ailing, Songming, Tingyu, et al. (2017). Comprehensive school based intervention to control overweight and obesity in China. Asia Pac J Clin Nutr. 26(6): 1-12. https://doi.org/10.6133/apjcn.112016.05 .

In-lw S, Saetae T, Manaboriboon B (2012). The effectiveness of school-based nutritional education program among obese adolescents: A randomized controlled study. J Pediatr. 167(8): 1-5. https://doi.org/10.1155/2012/608920.

Murti B (2018). Prinsip dan metode riset epidemiologi (Epidemiological research principles and methods). Edisi ke 5 . Surakarta: Program Studi Ilmu Kesehatan Masyarakat.

NCD Risk Factor Collaboration (2017). Worldwide trends in body-mass index, underweight, overweight, and obesity from 1975 to 2016: A pooled analysis of 2416 population based measurement studies in 128.9 million children, adolescents, and adults. Lancet. 390 (10113): 2627-2642. https://doi.org/10.1016/s0140-6736(17)32129-3.

Nuttall FQ (2015). Body mass index. Nutr Today. 50(3): 117-128. https://doi.org/10.1097/nt.0000000000000092.

Ogden CL, Carroll MD, Curtin LR, Lamb MM, Flegal KM (2010). Prevalence of high body mass index in US children and adolescents, 2007-2008. JAMA. 303(3): 242-9. https://doi.org/10.1001/jama.2009.2012.

Pbert L, Druker S, Barton B, Schneider, Olenzki KL, Gapinski Osganian, et al.
(2016). A school-based program for overweight and obese adolescents: A randomized controlled trial. Obes Rev. 14(8): 645-658. doi: 10.1111/obr.12035. Schwartz, Michael W, Seeley, Randy J, Zeltser, Lori M, Drewnowski, et al. (2017). Obesity pathogenesis: An endocrine society scientific statement. Endocr Rev. 38(4): 267-296. https://doi.org/10.1210/er.2017-00111.

Simmonds M, Llewellyn A, Owen CG, Woolacott N (2016). Predicting adult obesity from childhood obesity: a systematic review and meta-analysis. Obes Rev. 17(2): 95-107. doi:10.1111/obr.12334.

The GBD (2017). Health effects of overweight and obesity in 195 countries over 25 years. N Engl J Med. 377(1): 13-27. doi: 10.1056/NEJMoa1614362.

UNICEF (2021). Prevention of overweight and obesity in children and adolescents. https://www.unicef.org/search?force $=$ o\&query $=$ obesity $+\&$ created $\% 5-$ Bmin\%5D=\&created\%5Bmax\%5D=

Verjans J, Sacha RB, Ilona,Van K, Dave HH, Kremers, Stef PJ, et al. (2018). Effectiveness of school-based physical activity and nutrition interventions with direct parental involvement on children's BMI and energy balance-related behaviors A systematic review. PLOS ONE. 13(9): 1-24. https://doi.org/10.1371/journal.pone.0204560.

WHO (2021). Obesity and overweight. https://www.who.int/news-room/fact-sheets/detail/obesity-and-overweight. 